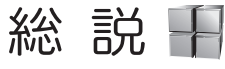

Review

\section{インドの石炭鉱業の現状と問題点 * 一厚層採炭法の改善 -}

\title{
The Present Situation and Issues in Coal Mining in India - Improvement of Thick Seam Mining Method-
}

\author{
by Hirofumi FURUKAWA ${ }^{\mathrm{a}}$, Kikuo MATSUI ${ }^{\mathrm{b}}$ and Hideki SHIMADA ${ }^{\mathrm{c}}$
}

a. JCOAL, 3-14-10 Mita, Minato-ku, Tokyo, 108-0073 (Corresponding author: E-mail furukawa@jcoal.or.jp)

b. Department of Earth Resources Engineering, Faculty of Engineering, Kyushu University, 6-10-1 Hakozaki, Higashi-ku, Fukuoka, 812-8581

c. Department of Earth Resources Engineering, Faculty of Engineering, Kyushu University, 6-10-1 Hakozaki, Higashi-ku, Fukuoka, 812-8581

India is the third largest coal producer in the world and has substantial coal reserves. It produced about 340 million tons of coal in 2002-2003. Open cast production accounts for $80 \%$ of the total output and the remaining $20 \%$ is from underground. The share of the underground output in the total production is expected to remain at the current level through 2010 even as the coal production increases. Despite its huge resource of coal, the quality of Indian coal is not so good. A considerable amount of good quality coal deposits in India lies in the thickness range of 5-12 m. However, an appropriate mining method for such thick seams could not be developed so far.

The coal's share of total electric power generation in India is $75.5 \%$ in 2001 . Because it is a reliable, domestic, and low-cost source of fuel, coal has played and will continue to play a significant role in the development of the Indian economy. Production, processing, and consumption of coal, however, can have significant environmental impacts, if not properly managed.

The paper describes the present situation of the Indian coal mining industry, discusses problems in thick seam mining methods, and proposes a new mining method for thick seams considering today's environmental issues in Indian coal mining.

KEY WORDS: Thick Seam Mining, Room \& Pillar Mining, Blasting Gallery Method, Longwall Mining, Spontaneous Combustion, Fly-ash

\section{1. 緒言}

インド共和国は，21 世紀の新たな経済大国として中国やロシ アとともに注目すべき国である。国土面積は日本の 8.8 倍 $(328.7$ 万 $\mathrm{km}^{2}$ ) あり, 2001 年の人口は 10 億 2,700 万人, 一人当たり GNP は 460US ドル，成長率は $4.4 \%$ である。エネルギー源別の 消費割合は，石油 $30.0 \%$, 天然ガス $7.8 \%$, 石炭 $55.6 \%$ であり, エネルギー自給率は 74\%である。電力構成では石炭が $75.3 \%$ を 占め最大シェアを占める。石炭に関して，インドは，中国，米国 に次ぐ大生産国であり，かつ大消費国である。2002 暦年生産は3 億 3,370 万トン, 2002/03 会計年度 (3 月から翌年の 2 月) は, 3

*2005 年 1 月 17 日 受付 4 月 13 日受理

1. 普通会員（財）石炭エネルギーセンター 企画部長

2. 普通会員工学博士 九州大学大学院教授 工学研究院地球資源システ 厶工学部門

3. 普通会員 博士 ( 工学) 九州大学大学院助教授 工学研究院地球資源 システム工学部門

[ 著者連絡先 ] FAX: 03-6400-5206(JCOAL) E-mail: furukawa@jcoal.or.jp

キーワード : 厚層採炭, ルーム\&ピラー採炭, 発破坑道法, 長壁式採炭, 自然発火,フライアッシュ
億 4,132 万トンである。

インドは，豪州にも匹敵する確認可採埋蔵量を保有しながら， 石炭関連技術情報は少ない。一般的にインドの石炭は，灰分が組 織中に一様に分布してその除去が困難な高灰分，低カロリー炭て あり，良質の原料炭が少ないという特徽は認知されているもの の，炭鉱現場技術の現状や問題点についての情報は少ないのが現 状である。

本稿では, 数回のインドでの現地調查を踏まえて, インドの石 炭鉱業について述べるとともに坑内掘りで厚層を採炭する種々の 方法について検討し，その問題点を指摘し，新たな採掘法を提案 するものである。

\section{2. 石炭資源 ${ }^{1)}$}

インドの石炭資源は, 古生代二畳紀の石炭と新生代第三紀の石 炭・褐炭に大別される。その大半を占める古生代二曽紀の石炭は 南アフリカ, 豪州等に分布しているゴンドワナ系であり, 主要炭 田は, Fig.1に示すようにインド亜大陸南東部の河川流域に集中 している。これらの主要堆積盆は雁行状に発達した正断層主体の 走向断層により区切られ，地層傾斜は一般的に緩い。ゴンドワナ 


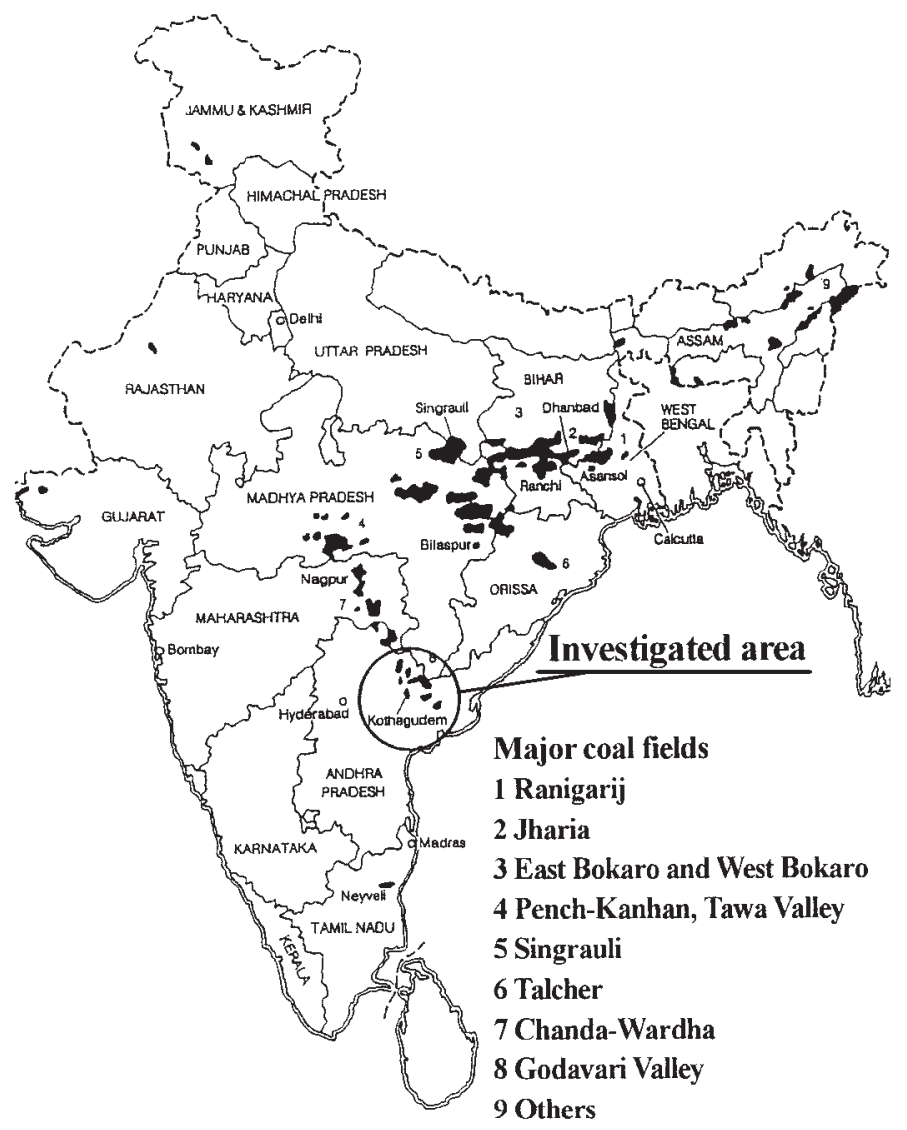

Fig.1 Location of coal fields.

系の石炭は，硫黄分，燐分は低いが，高灰分で，灰分中の無水珪 酸が多く摩耗性が高いこと, 鉱物質が石炭組織中に緊密に分布し ているため選炭による灰分除去が比較的に困難なことが特徴とし て挙げられる。

一般炭に関し, 炭鉱から $1,000 \mathrm{~km}$ 以上離れた発電所へ輸送す る電力用炭は灰分 $34 \%$ 以下という国内規制がある。原料炭は一 般的に灰分 $15 \sim 25 \%$ で良質原料炭は少ない。インドの石炭資源 は, インド石炭省資料によれば褐炭 200 億卜ンを含み確認埋蔵量 は 843 億 9,600 万トンである。

\section{$2 \cdot 1$ 生産及び保安状況 2$)$}

インドの石炭産業は，鉄鋼会社所有炭鉱など幾つかの例外を除 き, 1973 年に政府管理下におかれて大規模な露天掘りへの集中 投資が行われた。国有化当時の 75 百万トン程度の生産水準から 20 世紀末に目標 3 億トンの生産に引き上げるための投資が実施 された。2002 年度の炭鉱数は 559 であり, 殆どの炭鉱が政府管 理下にあり，その内，475 炭鉱を有する国営石炭会社 Coal India Limited (CIL) が，2 億 9,069 万トン $(85.2 \%)$, 州政府と中央政府 合弁の Singareni Collieries Company Ltd. (SCCL) が 77 炭鉱から 3,324 万トンを生産している。

生産方式では, 露天採掘が約 8 割, 坑内掘りが 2 割である。坑 内掘りの $50 \%$ 以上が穿孔・発破上人力積込みの旧来型のルーム \&ピラー法を採用している。稼行対象炭層は $4 \mathrm{~m}$ 以上の厚層が比 較的多く, 厚層 (インドでは厚さ $4.8 \mathrm{~m}$ 以上をいう) が埋蔵量の 約 $40 \%$ を占めるため, 厚層採掘技術が大きな課題として生じて いる。

石炭生産計画は，エネルギー政策のもと 5 ケ年計画が，計画委 員会 (Planning Committee) により策定されている。現在は 2006/07 年度を最終とする第 10 次計画である。計画供給能力は, 2006/07
Table 1 Number of fatalities for each accident in Indian coal mines.

単位:人

\begin{tabular}{|c|c|c|c|}
\hline 事由 & 2001年 & 2002年 & 備 考 \\
\hline 落 盤 & 30 & 23 & \\
\hline 側 壁 倒 壊 & 9 & 11 & \\
\hline 機械装置 & 35 & 23 & $\begin{array}{l}\text { ダンパー, トラック, } \\
\text { その他機械 }\end{array}$ \\
\hline $\begin{array}{l}\text { 運 搬 } \\
\text { (ロープ運搬) }\end{array}$ & 13 & 6 & \\
\hline 電 気 & 4 & 4 & \\
\hline 発破爆 薬 & 2 & 4 & \\
\hline 合計 & 106 & 82 & \\
\hline
\end{tabular}

Table 2 Number of fatalities for mining method in Indian coal mines.

単位: 人

\begin{tabular}{|c|c|c|c|}
\hline & 2001年 & 2002年 & 備 考 \\
\hline 坑 内採 掘 & 67 & 50 & \\
\hline 露 天 採 掘 & 26 & 19 & \\
\hline 地表 & 13 & 13 & \\
\hline 合 計 & 106 & 82 & \\
\hline
\end{tabular}

年度 4 億 500 万トン, 第 11 次計画最終年度 2011/12 年度で 5 億 2,500 万トンである。

保安状況は, 事故強度率や実労働時間等の詳細なデータは不明 であるが, Table 1 及び Table 2 に示すように 2001 年は 106 件, 142 名で, 2002 年の炭鉱事故件数 82 件で死亡者数 98 名である。 坑内掘りでの死亡事故は 2001 年 67 件が 2002 年には 50 件となっ ている。

坑内掘りは, 年産 5,000 6,000 万トンの水準で停滞している。 
長壁式 ( 以下, LW と略す) 切羽は 2001 年度で 12 切羽あり, 技 術協力では, 豪州, カナダ, 中国, フランス, ドイッ及びロシア が共同研究を立ち上げている。

需要は，第 10 次需要見通し(2002-2007 計画) では 4 億 6,050 万トン, 11 次計画末 (2012) の国内需要は 6 億 2 千万トンであり, 現状の生産計画では, 2007 年に 5,500 万トン, 2012 年に 9,500 万 トンの供給不足に陥る見込みである。

\section{$2 \cdot 2$ 石炭産業の現状と課題}

技術的に低水準の中小坑内採掘炭鉱が多くあり, 生産量は $10 \%$ 以下に過ぎないが，労働者数が多いため，雇用確保が社会問 題化しており，炭鉱の整理を困難にしている。また，坑内掘り炭 鉱の開発に際し，生産設備の輸入と高度な技術指導並びに巨大な 初期投資の必要性が生じる。

保安課題としては, 識字率が $65 \%$ 程度のため, 保安向上を図 るためにも識字教育にも力を入れる必要がある。また，350〜 $650 \mathrm{~m}$ 深部区域の通気への問題もある。例年 5 月頃に外気温が $47^{\circ} \mathrm{C}$ 以上となり, 深部 $350 \mathrm{~m}$ 以深の展開に際しては, 通気対策が 必要である。さらに, LW 切羽における堅硬天盤制御，採掘機械 の遠隔制御，坑内火災対策・払跡密閉技術，リスク管理，混炭技 術及び坑内通信システム導入が大きな課題である。

\section{$2 \cdot 3$ 調査した鉱山の現状と問題点}

$2 \cdot 3 \cdot 1$ Singareni Collieries Company Ltd. (SCCL) SCCL は 1889 年に操業を開始した Andhara Pradesh 州政府 51\%・中央政 府 $49 \%$ 出資の炭鉱会社で, Fig.1 に示すようにインド東南部 Andhara Pradesh 州に坑内掘り炭鉱 55 と露天掘り鉱山 12 を保有 している。2002/03 年度の生産量は 3,324 万トン, 従業員は 97,000 人である。2001/02 年度の生産 3,238 万トンからは微増で あるが，2006/07 年度は 3,613 万トンを計画している。また，坑 内掘り炭鉱では 5 つの LW が稼衝している。2001 年度ではイン ドで 12 の LW 切羽が稼働しており，CILに 7 切羽, SCCLに 5 切羽である。

LW の坑道展開は Alpine-AM50-Road-Headerにより行われ，天 盤ボルトと W- ストラップと 40 トン水圧鉄柱による支保である。 なお，ボルトシステムはすべてインド製であり，掘進速度は 3 〜 $4 \mathrm{~m} /$ 日である。

$\mathrm{LW}$ 切羽は $150 \mathrm{~m} \times 1000 \mathrm{~m}$ 程度であり比較的地質条件は安定し ている。切羽支保は 4 本レッグの 800 トン能力のチョック・シー ルド枠であり，ダブルレンジングドラムカッターにより採炭が行 われている。インドではす心゙てがこのタイプの自走枠であり， SCCL の GDK-9 Incline 炭鉱では中国製も 1 ユニット購入して使 用している。LW での問題は石炭が比較的固く，直接天盤も強固 であり払跡で吊天状態になるため生産性が低いことであり，この 改善が大きな問題として残っている。

坑内通信の重要性を認識し坑内無線システムの導入に意欲を 持っている。日本との協力関係が出来ることに期待している。

(a) GDK-No.2 炭鉱この炭鉱は週 6 日操業，8 時間三交代 制である。ルーム\&ピラー採炭 $(40 \sim 60 \mathrm{t} /$ 日 $)$ で，切羽人員 18 人 (うち積込運搬 10 人) が 12 切羽に割り当てられる。人員は 940 人, $500 \mathrm{t} /$ 日生産で, 採掘跡は人力充填する。川砂を充填 材に用いているが将来的に川砂の使用は禁止される見込みであ り，露天採掘の捨石を利用する計画がある。筆者らは，ガス干涉 計とマルチガスモニタを持参しガス測定したが，ガスは少ないこ とが確認された。また, 日本の坑内無線通信の坑内デモンスト レーションを実施した。

（b） GDK10A 炭鉱 GDK-10A Incline 鉱は，1985 年に開坑
した生産能力 77 万トン / 年 (LW60 万トン), 従業員数 1,118 人 の坑内掘り炭鉱である。可採炭量は 1,290 万トン, 採掘深度は $245 \mathrm{~m}$ であり, 1990 年に生産開始，LWを1994 年に開始した。 操業は 8 時間三交代制である。採炭切羽は，ドラムシアラとシー ルド枠の組合せで，推定投資額 $12 \sim 13$ 億円である。切羽長は $120 \sim 150 \mathrm{~m}$ ，片盤長 $1,000 \mathrm{~m}$ 程度，炭層傾斜は $9.5^{\circ}$ と比較的地質 条件は安定しており，最大日産は11,080 トンである。本鉱山で は小断層が散見されるにも拘わらず一部に無支保坑道がある。一 部岩粉散布不足はあるが，坑内の整理整頓は非常に良い。

（c）VK7 坑生産は LW (1,000 トン/日) と半機械化ルーム \& ピラー採炭並びに掘進炭で, 日産 2,200 トン, 年産 70 万トン である。立坑方式で深度は $-240 \mathrm{~m}$, 立坑運転速度は $4 \mathrm{~m} / \mathrm{sec}$ で，ドイツ製チェアリフト $(150 \mathrm{~kW}$ 運行区間 $480 \mathrm{~m}$, 運行速度 $8 \mathrm{~km} / \mathrm{h})$ を導入して道中時間短縮と疲労軽減を図っている。

直接天盤は砂岩（一軸圧縮強度 $=40 \sim 80 \mathrm{MPa}$ ) で，採炭作業の 進行に伴い突然崩落する可能性がある。また, 払跡残炭の存在は 自然発火の可能性も否定できない。現場管理者は, 自然発火が保 安面での不安全要素であり, 自然発火防止技術の導入を期待して いる。坑内の必要箇所は岩粉散布が実施されている。

将来的には，採掘区域の深部化に対応した可燃性ガスの測定， 監視及び通気管理対策が求められる。坑内通信技術への期待が大 きいが，坑外も通信手段が貧弱で，かつ，炭鉱が広範囲に存在す るため, 緊急事態に対応できる体制確立も求められる。安全で高 実収率かつ経済的な厚層採掘技術開発に対する期待が大きい。

(d) GDK-10 Incline 炭鉱後述の $3 \cdot 1 \cdot 9$ を参照。

$2 \cdot 3 \cdot 2$ Western Coal Company Ltd. (WCL) WCL は CIL の会社であり，インドの 3 大炭田の Madhya Pradeshにある 10 力所の区域の露天掘り及び坑内掘り鉱山から年間約 3,700 万卜 ンの石炭を生産している (Fig.1 参照)。このうち, 露天掘りが 2,705 万トンで坑内掘りは 995 万トンであり, 生産性は露天掘り が坑内掘りの 5 倍以上となっている。

坑内掘りはルーム\&ピラー法であり，機械化されていない炭鉱 も多くある。今回は，WCLの炭鉱としては，Seoneer No.2 炭鉱， Tandsi 炭鉱及び DRC 炭鉱の 3 力所を調査した。

(a) Seoneer No.2 炭鉱旧来型のルーム\&ピラー法で年間 約 25 万トンの石炭を生産している。開発坑道は層厚 $5 \sim 6.5 \mathrm{~m}$, 傾斜 $1 / 5$ の No. 5 層の上部側に発破掘進される。幅 $3.5 \mathrm{~m} \times$ 高さ $3.0 \mathrm{~m}$ の矩形坑道は, $1.5 \mathrm{~m}$ 長, $19 \sim 22 \mathrm{~mm}$ 径の 3 本のルーフボル トと $2.5 \mathrm{~m}$ 長の W- ストラップで， $1 \mathrm{~m}$ 間隔で支保される。各穿孔 は手持ちのオーガー式の穿孔機で行われ，ボルトの打設は早強セ メントのカートリッジを水につけた後ボルト打設孔に入れて行 う。なお, 1 回の発破掘進長は $1 \mathrm{~m}$ である。天盤の悪い箇所や坑 道交差部では，W-ストラップ間に増しボルトを打設し，また使 い古しの鋼製ロープを用いた縫い付け (rope stitching) を行ってい る。

ピラーの大きさは $22.5 \mathrm{~m} \times 22.5 \mathrm{~m}$ で，現在の採掘深度は $85 \mathrm{~m}$ である。地山制御問題としては軟弱な直接天盤が $4 \mathrm{~m}$ の高さに あって砂岩境界面まで崩落しやすいことである。

掘進発破やピラー回収時の採掘した石炭は 4 台の SDL ( サイド ダンプローダ）か 3 台の LHD (ロードホールダンプ )により積込 みされている。

（b） Tandsi 炭鉱 年間 70 万トンを機械化ルーム\&ピラー法 で採炭している。3つの CM (コンティニュアスマイナー) パネ ルと 3 つの LHD パネル（採炭は発破）を持っている。

採炭は層厚 $4 \mathrm{~m}$ の No.1 層で行っており， $1.2 \mathrm{~m}$ の炭層を下盤に 残し, 幅 $3.5 \mathrm{~m}$, 高さ $2.8 \mathrm{~m}$ で坑道展開している。現在は坑道展開 
のみで, すべての展開が終わればピラー回収を開始する予定であ る。

生産性を上げるために，JOY $12 \mathrm{CM} 30 / 40$ のボルターマイナーと シャトルカーによるシステムを開始するために，イギリスの RMT コンサルタント (豪州のコンサルタント SCT の系列会社) による地山応力や支保設計が行われた。その結果，水平応力が垂 直応力よりも約 2 倍大きいことが計測され，マイナ一採掘とシャ トルカー走行のために坑道幅を $4.8 \mathrm{~m}$ に拡大寸る必要が生じ，そ れに適応した支保システムとして $4.4 \mathrm{~m}$ 長 W- ストラップ併用の ケミカルレジンによる $2.4 \mathrm{~m}$ 長ボルト 5 本 (垂直打設) が提案さ れた。

(c) DRC 炭鉱本鉱山は 3 つ坑内掘り炭鉱を有しており, 筆者らはその 1 つを調査した。採掘は旧来型のルーム\&ピラー法 であり，年間約 33 万トン生産している。坑道の方向により天盤 の崩落がはっきりしており, 走向方向の水平方向応力が垂直応力 より大きいことが予測される。坑道展開やピラー回収は発破によ り行われ, 天盤は $1.5 \mathrm{~m}$ 長のボルト 3 本とロープ縫い付けで支保 されている。ボルト打設は手持ちのオーガー穿孔機と早強セメン トにより行われる。

軟弱な層状頁岩が $4 \sim 5 \mathrm{~m}$ の高さまで崩落しており，適切な天 盤挙動モニタリングシステムと支保システムの確立が必要であ る。また, 払跡での石炭の自然発熱が多く認められ，ガス・坑内 火災探知モニタリングシステムの導入が必要である。

\section{3. 厚層採掘法の現状と問題点 ${ }^{3)}$}

インドにおいては炭層の厚さが $4.8 \mathrm{~m}$ を超える場合を厚層と称 しているが，これは $4.8 \mathrm{~m}$ を超えるような炭層厚さではベンチ式， 寸なわち旧来型の人力による安全なルーム＆ピラー法による単一 のスライス以外に効率的に採掘できないことによる。今日では新 しい採掘技術・機器の導入で $6 \mathrm{~m}$ までの厚さまで単一スライスで の採掘が可能となっているので, これまでの厚層の定義を修正す る必要がある。

インドでは可能採掘埋蔵量の $40 \%, 221$ 億トンの石炭が厚さ $4 \mathrm{~m}$ 以上の炭層となっている。

インドでは 1973 年に石炭鉱業が国営化されるまでは厚層は, 例え採掘深度が浅くても機械化露天掘りには莫大な投資を必要々 するため, 主に人力によるルーム\&ピラー法で採掘されていた。 国営化の後, 多額の投資がなされ当時の 7500 万トンの生産レ心゙ ルから 20 世紀の終わりまでに 3 億トンレベルに生産を増強する といら積極的な働きかけがあった。その結果，1985～86 年にお いておよそ 1 億 5 千万トンの生産の $50 \%$ が露天掘り採掘による ものとなり，そのほとんどは採掘限界内の厚層からであった。こ の傾向は, そのまま続き, 現在では全採掘量の $80 \%$ が露天掘り からのものである。浅部にある厚層の炭層のほとんどが年間 1 千万トン以上の生産能力を持った大規模露天掘り鉱山により採掘 されている。

今日，坑内掘りによる生産量の $20 \sim 25 \%$ が厚層からのもので ある。この生産はほとんどがルーム\&ピラー法による採掘と流送 充填を用いたピラー回収によるものである。今後生産を増大しよ うとするならば, 厚層からの生産を増大することがきわめて重要 となる。しかし, 現在の採炭方式では, 最適な充填材料の不足や 充填の高コストに伴い低い生産性とならざるを得ず, 生産性向上 のためには, 厚層を適切に採掘できる坑内掘り技術の確立が必要 である。すなわち，上部にある厚層を完全にうまく採掘できなけ れば，下部にある層からの生産性を増加することは不可能であ り，それゆえ既存の炭鉱の生産性を増大寸る可能性もまた大きく
制約を受ける。

インドでは，これまでに厚層を採掘するために多くの方法や技 術がいくつかの国々から導入された。これまでに試みられた方法 とその問題点を以下に述べる。

$3 \cdot 1$ 旧来型のルーム\&ピラー法

インドにおける典型的な厚層の採掘は，上部方向に 1 段厚さを 一般的には $2.4 \sim 3 \mathrm{~m}$ として 2 段から 4 段のスライスで充填を用 いるルーム\&ピラー法である。この採炭法の問題点としては以下 の点が挙げられる。

1) この採掘法では第 3 段目やそれ以降のスライスの採掘後, 天盤制御問題が生じ，採掘作業を放棄せざるを得なくなって いる。

2）採掘時の石炭の採掘口スが大きく，未回収の石炭の自然発 火による火災が多く生じている。

3）充填した砂の上での人力による石炭の積込作業は困難を伴 い，石炭が砂と混入し品位を低下させる場合が多い。

4）充填サイクルのために生産性はきわめて低く, 平均して 250 ～ 300 トン/日である。

5）生産性を増加寸るには, 採掘切羽を増大寸る必要があるが, 通気上の問題が生じる。

ケービングを用いるルーム\&ピラー法もまた $8.4 \mathrm{~m}$ までの厚層 採掘に用いられた。炭層は天盤や下盤に沿って高さ $3 \mathrm{~m}$ で坑道展 開され，形成されたピラーはピラー回収時に中割される。中割坑 道は全層高にわたって深く, あるいは高く掘られ, その後充填さ れる。残されたピラー部 (ストック) は上部スライスが絶えず下 段スライスより $2 \mathrm{~m}$ 先行していく多段スライスで回収される。上 部スライスは短い支柱で支保され，下部スライスはより長い支柱 が用いられる。ケービングを用いたルーム\&ピラー法による厚層 採炭の課題としては，以下の通りである。

1）天盤制御が常に問題となり，ピラーやストックが採掘跡に 残される。

2）適切な大きさを持った長い支柱の確保がきわめて難しい。

3）石炭の実收率が低く，わずか $50 \sim 60 \%$ である。

以上の結果, ルーム\&ピラー法による単一スライスでの回収は 高さ $4.8 \mathrm{~m}$ までに制約される。

その後，スライス間に十分な厚さの石炭を挟みとして残して採 掘された。ピラー回収時，ピラーは中割され，上部から下部方向 に採掘される。このシステムでは各スライスのピラーが上下で しっかりと垂直的位置関係を保っているかがより重要となる。し かし，以下の問題点が指摘される。

1）ピラーの垂直的位置関係を保つことが非常に難しい。

2）各スライス間に残した挟みの石炭の破壞が生じや寸い。

3）採掘切羽や坑道の数が増大寸るために通気問題が難しくな る。

4）挟みの石炭の崩落やピラーの早期の崩壊により自然発火が 生じやすくなる。これらのパネルは効果的に密閉することが できず， 1 力所から発生した火災が隣の箇所に広がることも ある。

\section{2 拡幅坑道法}

この方法は，深度 $45 \mathrm{~m}$ にある層厚 $16.5 \mathrm{~m}$ ( 挟み $3 \mathrm{~m}$ ) において初 めて適用された。ここでは，地表に町や河川，道路，鉄道などが あるために大量の石炭をピラーとして残すルーム\&ピラー法が従 来から用いられてきた。

採掘はパネルを下部層と上部層をルーム\&ピラー法で開発し, 坑道幅を拡幅する方法である。開発坑道は幅 $3.6 \mathrm{~m}$ で掘進され, 木柱と木積により支保される。その後, この坑道を木柱と木積を 
用いて $9 \mathrm{~m}$ に拡幅して行くものである。まず，下部層 $6.4 \mathrm{~m}$ を $3.2 \mathrm{~m}$ 厚さの 2 段スライスで採掘する。下部層の 1 段スライスは 下盤側に高さ $3.2 \mathrm{~m}$ で取り, 充填の後 2 段目スライスを採掘し, 充填する。その後, 上部層を同様な方法により各 $3.6 \mathrm{~m}$ 厚さの 2 段スライスで採掘する。

採炭実收率は従来の方法では 30〜35\% であったが，この方法 により $50 \%$ を超えるようになった。しかし，この方法の欠点は 依然として実収率が低く，払跡天盤が良好なものに限られている ことである。

\section{$3 \cdot 3$ 単一スライスによる長壁式採掘}

従来の支保システムを用いた単一スライスで $3.5 \mathrm{~m}$ を超える厚 さでのロングウォールは，払跡での天盤崩落が地山制御上困難な ために好まれていなかった。しかし，1960 年代にロシアやチェ コスロバキアにおいて $5 \mathrm{~m}$ までの厚層採掘に用いるシールド枠が 開発された。また， $4.5 \sim 6 \mathrm{~m}$ の厚層採掘のためにポーランドや フランスにおいてもシールド枠が開発された。インドでは, $4.7 \mathrm{~m}$ の層を単一スライスで採掘するために導入された。これはフラン スのコンサルタント会社 CdFI との共同で行われた。用いられた シールド枠は $68 \sim 84$ トン $/ \mathrm{m}^{2}$ の支保抵抗を持ち, 支保高さは $2.2 \sim 4.7 \mathrm{~m}$ である。

稼行中 LW 切羽の実績は非常にめざましいものであった。2 番 目のパネルでは, 1 日当たり最大 1 万トン以上の生産があった。 最初の 2 つのパネルでの採掘は良好であった。当然のことなが ら, 両パネルでいくつかの地山制御問題が生じ, 合わせて数多く の日数間，切羽を止めざるを得なかった。

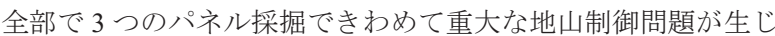
た。3 番目のパネルでは激しい動的地圧が作用し，切羽は崩壊し た。そのため，最終的には切羽を止めざるを得なかった。

この方法では，大きなシールド枠の維持管理も難しく，また採 掘可能厚さがシールド枠の高さに限定され，6m を超える厚層で は採掘ができない。このような欠点を克服するために，Fig.2に 示すようにトップコールケービング法が開発された。中国では 種々の改善がなされ，現在では $10 \mathrm{~m}$ を超える厚さの炭層にも用 いられ，大きな生産性を上げている4)。

この方法は, $7.2 \mathrm{~m}$ 厚の炭層で試みられた。 $\mathrm{LW} の$ 片盤長は $205 \mathrm{~m}$ で，切羽長は $100 \mathrm{~m}$ であった。 $2.4 \mathrm{~m}$ 厚さのスライスが下盤 に沿ってとられた。ドラムカッターがスライスを採掘すると，
シールド枠が前進し, 切羽コンベアも前進する。次にケービング シールド枠のボトムスライドプレートが引き込まれ，ケービング した石炭が後部切羽コンベアに落ち込む。後部切羽コンベアは回 収した石炭をステージローダーに運ぶ。適切に石炭を落とすため にケービングシールド枠の傾斜が油圧シリンダーにより調整され る。

この切羽は日産平均 80 トンで, その $48 \%$ はケービング炭で あった。しかし，下部スライスの採掘条件が悪い箇所での実収率 は $44 \%$ であった。時々大きな石炭塊が後部石炭落とし口で詰ま り，ハンマーや 2 次発破で破砕する必要があった。また，後部切 羽コンベアの前方部がこぼれ炭の山に乗り上がり，後部キャノ ピーの操作を妨害した。そのため，採炭実収率が悪く $60 \%$ 程度 であった。これは大きな問題であり，最終的には自然発火発生に 至り，パネルを水浸しにする必要があった。

トップコールケービング法の問題点は以下の通りである。

1）石炭が固いと上部に残した石炭はケービングで壊れず，回 収が問題となる。

2）難崩落性の天盤には適していない。

3）パネルの全石炭を採掘するのに必要な時間が自然発火の潜 伏期間を超えるので，火災発生の可能性がある。

\section{$3 \cdot 4 \quad L W$ 採掘によるスライシング}

最初は，厚層を $\mathrm{LW}$ とルーム\&ピラー法を用いてスライシング で採掘する方法が考えられた。炭層の下部を LW でまず採掘し, 砂を流送充填した後, 上部の石炭をルーム\&ピラー法で採掘する ものである。1970 年代初期から下部から LW のスライシングを 行い，同時に充填して厚層を採掘寸る方法が用いられた。以下に $2 つ$ 方法について述べる。

3・4 1 人工天盤下における上部から下部へのスライシン グとサブレベルケービング このシステムは 1967 年にフラン スの協力によりに導入された。採掘パラメータは, 層厚 $12 \mathrm{~m}$, 傾 斜 $1 / 5 \sim 1 / 8$, 被り $70 \mathrm{~m}$, 切羽長 $90 \mathrm{~m}$ である。炭層は各スライシ ング $2.4 \mathrm{~m}$ の 5 段で採掘された。各スライスは上段部の下盤に人 エマットを敷き詰めて上部から開始された。基本的な採掘システ ムはFig.3 に示すようなものである。4 番目のスライスは 5 段目 と 3 段目の中段坑道 (サブレベル) として採掘された。LW 切羽 は40 トン能力の鋼製摩擦鉄柱と $1.25 \mathrm{~m}$ 長さカッペで支保された。 支保間隔は $1.25 \mathrm{~m} \times 65 \mathrm{~cm}$ で，25トン $/ \mathrm{m}^{2}$ の評価支保抵抗を有し



Fig.2 Top coal caving longwall method. 
ている。 LW 切羽部の幅は最小 $3.75 \mathrm{~m}$, 最大 $5 \mathrm{~m}$ である。払跡側 は傾斜支保により強化された。

採炭は下透かしと発破であり, 切羽コンベアへの積込は人力で ある。最初のスライス採炭の間に天盤制御問題が生じた。払跡の 天盤崩落は不十分であり, 最初の荷圧は $40 \mathrm{~m}$ で生じた。そこで, 切羽始発部からの発破により強制的な天盤崩落が行われた。周期 的な荷圧は切羽の進行 $6 \sim 9 \mathrm{~m}$ 間隔で起こり, 天盤を相当悪化さ せた。しかし，天盤収縮は $2 ， 3$ 番目のスライス採掘では制御さ れた。3 番目スライス採掘の後, 下盤マットがかなり劣化したの で, 4 番目のスライスは最後 (5 番目) のスライス採掘と一緒にサ ブレベルケービングで採掘された。5番目のスライス切羽が進行 するにつれて, サブレベルケービングで採掘された石炭を捕収す るために天盤に金網が設置された。天盤の石炭は切羽後方で崩落 し，天盤金網にあけられた穴から回収されたが，10〜20\%の ケービング炭が払跡に残った。

この方法での石炭の実収率は良好であったが，生じた大きな問 題は, 後述するように LW 切羽の進行速度がきわめて遅いため全 スライスを採掘するまでの時間が非常に長く，加えて払跡への残 炭もあり，自然発火を起こしや寸いことおよび 3 段スライスを終 えるまでに金網が劣化してしまうこと等であり，その結果良い結 果を得ることはできなかった。人工天盤を敷き，サブレベル炭を 引き抜くことを習得しただけに終わり，この方法は 1980 年に別 の炭鉱で $5.4 \mathrm{~m}$ 厚さの炭層を 2 段スライスで採掘するまで顧みら れなかった。

この方法の欠点は以下の通りである。

1）生産性が低いので経済性がない。

2）ケービングしにくい天盤には適していない。

3）石炭が固いとサブレベルケービングで壊れず，回収が問題 となる。

4）パネルの石炭を採掘するのに必要な時間が自然発火の潜伏 期間を超えるので，火災発生の可能性がある。

5）人工ネットを敷き詰めるのが難しく, きわめて面倒である。
$3 \cdot 4 \cdot 2$ 流送充填を用いた下部からの傾斜スライシング

この方法は最初ポーランドの石炭鉱山で試みられた LW 採掘法 を改良したものである。この方法が層厚 $7.5 \mathrm{~m}$, 傾斜 35 度を有す る炭層に対して適用され，流送充填を用いた 2 段の傾斜スライス 方式で採掘された。

炭層には垂直距離 $100 \mathrm{~m}$ の間隔の水平坑道が設けられ，高さ $3.5 \mathrm{~m}$, 幅 $3.0 \mathrm{~m}$ の昇り坑道が炭層中に下盤に沿って $100 \mathrm{~m}$ 間隔で 掘進され, この水平坑道と繋がれた。下部の水平坑道は石炭の運 搬に, 上部水平坑道は材料の搬入に用いられる。中央部の昇り坑 道は隣接する 2 つのパネルからの石炭を運搬するためのチェーン コンベアを備えていた。

炭層は $3.5 \mathrm{~m}$ 厚さの 2 段スライスで採掘された。下部水平坑道 に対して $20 \mathrm{~m}$ 幅の保安炭柱を残し，切羽は昇り向きに進行する。 2 つの切羽パネルは $25 \mathrm{~m}$ の距離を保って同時に採掘・進行し, 1 方の切羽で採掘が行われ，もう一方の切羽では充填が行われる。

この方法の大きな問題点は以下の通りである。

1）支保が充填砂の上で行われ，また従来の木柱支保であるの で天盤制御が問題となる。

2） 2 段以上のスライスで採掘されるような厚層では天盤制御 が難しい。

3）充填は時間とコストがかかり，経済性が低い。

3 - 5 砂の流送充填を用いた下部から上部への水平スライシ ング

この方法は, ポーランドの石炭鉱山で用いられた方法で, イン ドでは $1974 \sim 76$ 年に $300 \mathrm{~m}$ 深度にある厚さ $22 \mathrm{~m}$, 傾斜 $27 \sim 35$ 度の炭層に適用された。2つの LW パネルが下盤に沿って $100 \mathrm{~m}$ 間隔で 3 本の昇り坑道により $200 \mathrm{~m}$ と $300 \mathrm{~m}$ レベルの水平坑道間 に作られた。厚さ $3 \mathrm{~m}$ の 33 段の水平なスライスで採掘すること が計画され, 水平な立入坑道が下盤から上盤に向かって掘進さ れ， $22 \mathrm{~m}$ の厚層中におよそ $47 \mathrm{~m}$ 長さの切羽が作られた。

採炭は発破により行われ，木柱と木梁により支保された。切羽 が水平で, 炭層が急傾斜であり, 層理面を横切って採炭が行われ



Fig.3 Multi-slicing method using wire meshes as the false roof. 


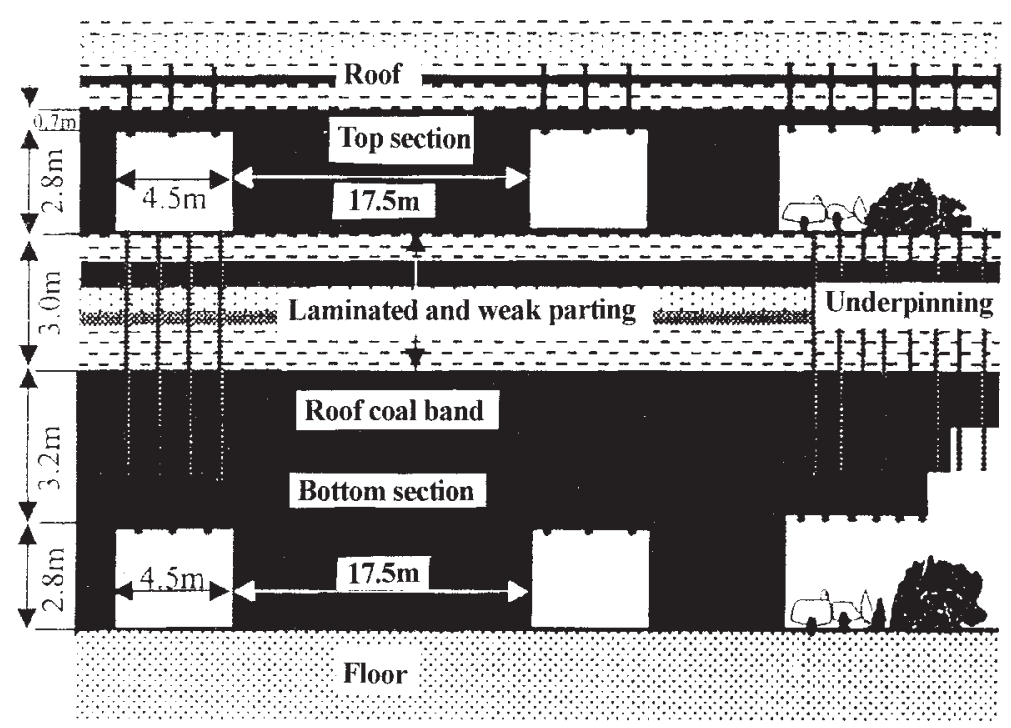

Fig.4 Simultaneous depillaring by underpinning and roof bolting.

るために凹凸のブロック状天盤の安定性が問題となった。この問 題は不十分な充填作業により悪化し，上部スライスでさらに激し くなり, パネルは数スライスの採掘の後放棄された。

3・ 6 充填を併用した修正ルーム\&ピラー法

この方法は最初，厚さ $5 \sim 5.5 \mathrm{~m}$ ，傾斜 $1 / 5$ の層において 1930 年代に適用され，幅 $8.5 \sim 9 \mathrm{~m}$ ，長さ $75 \sim 100 \mathrm{~m}$ のチャンバーが $12 \sim 15 \mathrm{~m}$ 幅のピラーを挟んで作られ，実収率は 35\% であった。

この方法が別の炭鉱において厚さ $4.5 \sim 5 \mathrm{~m}$, 傾斜 $50 \sim 60$ 度 の炭層で再度試みられた。まず， $100 \times 100 \mathrm{~m}$ の大きさのパネル が傾斜に沿って $15 \sim 20 \mathrm{~m}$ 間隔の坑道でサブブロックに分割され る。この $2 つ の$ 坑道は $10 \mathrm{~m}$ 間隔で掘進されるルーム坑道により 繋げられる。このルーム坑道の幅を従来の穿孔発破により徐々に $7 \mathrm{~m}$ まで拡幅し，高さも $4.5 \sim 5 \mathrm{~m}$ とする。発破した石炭の一部 は天盤穿孔の際の足場として残寸。 $40 \times 7 \times 7 \mathrm{~m}$ のチャンバー 全体が発破された後石炭が搬出され，その後充填された。この チャンバーは 15 日間採掘とその後の 6 日間の充填で，合計 2,500 トン採掘され，実収率は $60 \%$ であった。しかし，チャンバー内 は支保が無く，軟弱な天盤では天盤制御が問題となり，生産量も 生産性も悪いものであった。

\section{3・ 7 ケーブルボルトを用いた長孔発破法}

この方法は厚さが $3 \sim 8.27 \mathrm{~m}$ と大きく変化する炭層において 適用された。ここでは下部の $4.8 \mathrm{~m}$ だけを採掘し，上部はピラー 回収の時に採掘していた。払跡では $4.8 \mathrm{~m}$ を超える高さの天盤が, しばしば崩落し，自然発火問題を引き起こしていた。そこでこの 層をケーブルボルトで支保して採掘する新しい方法が導入され た。

坑道は炭層下盤に沿って高さ $3 \mathrm{~m}$ で掘進され，天盤ボルトによ る支保に加え, 坑道天盤の $1.5 \mathrm{~m}$ までケーブルボルトが打設され た。そこでピラーが中割され，中割坑道も同じくケーブルボルト が打設された。5m 幅のスライスが掘削，支保された。そこで $1.8 \mathrm{~m}$ の上部炭層部はケーブルボルトで支保された天盤下で採掘 される。最終的には, 3 番目のスライスの $1.7 \mathrm{~m}$ 厚さの石炭が発 破される。穿孔はジャンボドリルにより行われ，積込は SDLに より行われる。特別な爆薬を用いて $4 \sim 5 \mathrm{~m}$ 厚さの天盤石炭を 1 回の発破で採掘しようと努力がなされている。また，オペレータ が発破された天盤下に入らないようSDL は遠隔操作されている。
3・8 ケーブルボルトを用いた上部下部層同時採掘法 5)

Chirimiri 炭鉱の Zero 層は $4.5 \sim 6 \mathrm{~m}$ 厚さの下部層と $3.6 \mathrm{~m}$ 厚さ の上部層からなっており，上下部層間に $3.0 \sim 4.5 \mathrm{~m}$ の厚さの挟 みを含んでいる。上部，下部の石炭ピラーは垂直方向にきちんと 重なるように設けられる。ケーブルボルトとして，上部坑道の下 盤から $19 \mathrm{~mm}$ 径，長さ $4.5 \sim 6 \mathrm{~m}$ の古ロープを $1.2 \mathrm{~m}$ 間隔で打設 する。Fig.4にこの採掘法の 1 例を示す。遠隔操作の LHD がス ライスの石炭の積込に用いられ，坑道交差部や中割坑道，スライ ス坑道は W- ストラップと天盤ボルトにより支保されている。

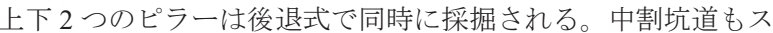
ライスもまた上部からケーブルが打設される。スライスの天盤の 石炭が発破されると，石炭はケーブルボルトの支保に支えられ， また挟みの崩落もケーブルボルト打設によりすぐには生じない。 この方法の問題点は, ケーブルボルトの効率的な打設であり, 最 適な機器の開発が必要である。

3.9 発破坑道法 (BG 法 :Blasting gallery method) $)^{6}$

この方法はルーム\&ピラー法で開発された厚層のピラーを回収 するために, 1987 年にフランスの CdFI の協力でインドに初めて 導入された。その後, SCCLの Godavarikhani 炭鉱や GDK-10 Incline 炭鉱等の厚層のピラー回収に適用された。

以下に現在の GDK-10 Incline 炭鉱での実例を示す。



Fig.5 Blasting gallery (BG) method. 


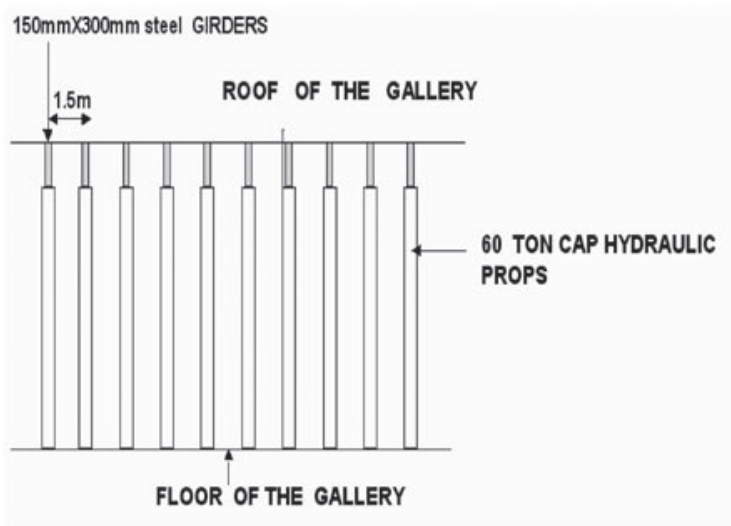

SIDE VIEW

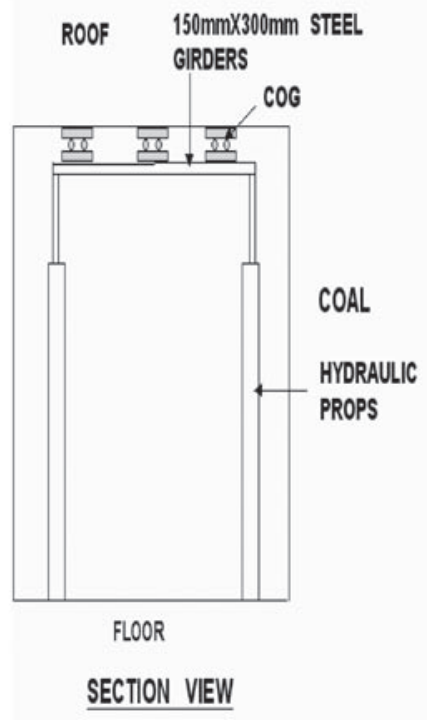

Fig.6 Roadway support system.

採掘パネルは, Fig.5に示すように厚い炭層最下部に発破掘進 により先進坑道を走向方向に約 $40 \mathrm{~m}$ 間隔で設け, その後, これ を約 $60 \mathrm{~m}$ 間隔で設ける卸方向への立入で接続し，約 $40 \times 60 \mathrm{~m}$ の大きさのピラーを形成する。その後, 立入からピラーの中央部 に中割坑道を掘進し, ピラーの石炭の採掘をパネル最下部のピ ラーから開始寸る。これらの坑道は矩形であり, 幅 $4.2 \mathrm{~m}$, 高さ $2.8 \mathrm{~m}$ が基本である。

基本的な支保システムは, $1.5 \mathrm{~m}$ 長, 直径 $22.0 \mathrm{~mm}$ の鋼製ボル トを $1 \mathrm{~m}$ 間隔で坑道天盤に 1 列に垂直に 4 本早強セメントミルク で打設する。坑道交差部では, $15 \times 15 \mathrm{~cm}$ の鋼製ビームと鋼製支 柱により補強される。なお, 側壁や炭層部の石炭の強度は大き く, 一軸圧縮強度は $30 \sim 50 \mathrm{MPa}$ である。インドの石炭の特徵は このように強度が大きいことである。したがって, 炭層条件のよ いところでは無支保でも十分である。

ピラー採掘の開始により払跡周辺には大きな先行圧が作用し始 めるので, ピラー回収ラインから $30 \mathrm{~m}$ 区間の坑道支保補強のた めに Fig.6 に示すように能力 40 トンの水圧鉄柱と鋼製ビームを $1.5 \mathrm{~m}$ 間隔で建て付ける。ピラーの回収は深度の深い方のピラー から開始し, ピラー回収ラインが開発のための先進坑道 ( 走向坑 道) とおおよそ 60 〜 70 度になるように進める。

長孔穿孔はFig.7, Fig.8に示すように, 油圧ジャンボドリルを 用いて, $1.5 \mathrm{~m}$ 間隔，すなわち水圧鉄柱とビーム支保の間に坑道

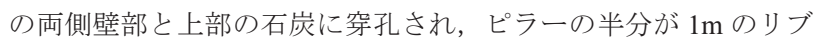
を残して発破される。Fig. 8 に示寸ように 1 坑道での 1 発破で約 33 個の発破孔が穿孔され, 特別な P3 爆薬が発破に用いられる。 この爆薬の装填のためにプラスチックのスペーサーが爆薬間に用 いられる。

破砕された石炭は払跡に落ちてくるが, LHDにより積込され， 後方のチェーンコンベアに運搬される。積込作業が支保坑道内で 行われる場合はオペレータが LHDに乗り込んで行うが，払跡内 での作業になるとオペレータは坑道内からリモートコントロール でLHD を操作する。

払跡のメタンガス管理は, 坑道内からの長孔ボーリングにより 払跡天盤のガスの採取し，分析することで行っている。

炭層上部の直接天盤は塊状で, 強度の大きな砂岩 (一軸圧縮強 度 $=40 \sim 80 \mathrm{MPa}$ ) であるため, ピラー回収が進行し払跡天盤の露 出面積が増えるにしたがって突然大きな固まりで崩落する可能性
がある。このような天盤岩石の崩落により圧風が起こり, 坑内作 業員や使用機器に甚大な被害を及ぼすおそれがある。これを防止 するために, Fig.9に示すように払跡天盤に長孔発破を行い，天 盤の岩石を制御して崩落させるよう努めている。

しかしながら，長孔ボーリングの作業の煩わしさやその効果の 低さから水圧破砕の適用を試みている。水圧破砕による亀裂の発 生と岩石の含水により強固な天盤の力学的特性や崩落性は大きく 改善されると思われる。払跡天盤に水圧破砕を行う方法が試みら れている。水圧破砕による払跡天盤の制御された状態での崩落の 成果は未だ認められていないが, 難崩落性の天盤に水圧破砕によ り的確に亀裂を生じさせるには, 地圧条件や岩盤の強度特性を十 分把握する必要がある。

この方法の利点をまとめると以下の通りである。

1）単一スライスによる採掘で厚い炭層を採掘できる。

2）採炭実収率は，これまでのルーム\&ピラーが $35 \sim 45 \%$ で あるのに対して $70 〜 90 \%$ ある。

3）炭層条件が変化しても柔軟に対応できる。

4）使用機器の移設時間が少ないので, 生産ロスが少ない。

5）初期投資が少ない。

一方，欠点は以下の通りである。

1）LHD の能力により炭層傾斜が 9 度以内までしか適用でき ない。

2）発破石炭の完全回収ができないので, 石炭実収率が低く, また払跡での自然発火の発生がある。

3）メタンガスの多い炭層には適用できない。

4）払跡での直接天盤の大規模な崩落による圧風発生の可能性 がある。

GDK-10 Incline 炭鉱での BG 法の採炭現場では, これまで何度 も払跡での自然発火によりピラーの回収を中断し，パネルを完全 密閉しており, その結果, 採炭実収率は $30 \sim 40 \%$ 程度となって いる。

この方法では，払跡の崩落石炭の完全回収による自然発火の防 止と払跡天盤の制御が大きな問題として生じている。これらの解 決がなされなければ, これに代わる新たな採掘法を開発する必要 がある。払跡での自然発火の問題には, 払跡の残炭が空気に触れ るのを抑制するために，石炭灰スラリーを散布して残炭表面を被 覆することで対処することができ，この散布システムの開発が必 


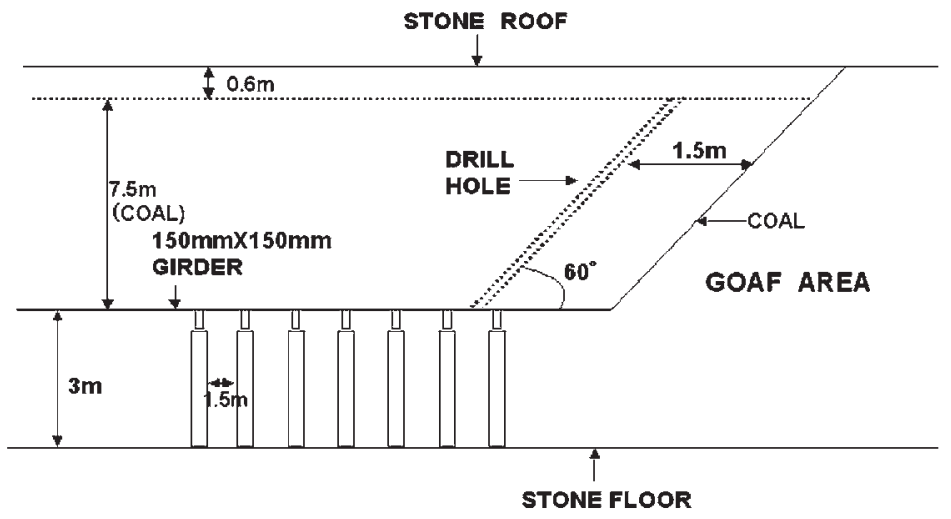

Section showing roof holes in ring blast

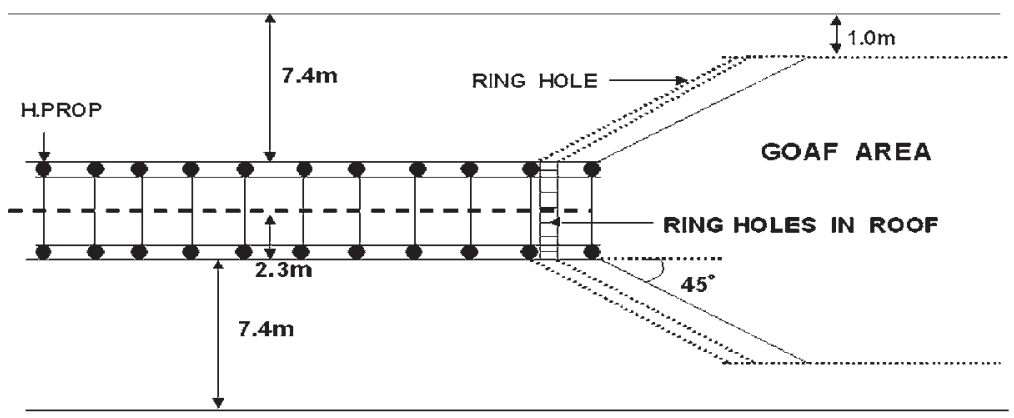

PLAN

Section showing side holes in ring blast

Fig.7 Ring blast in the roof and sidewalls.

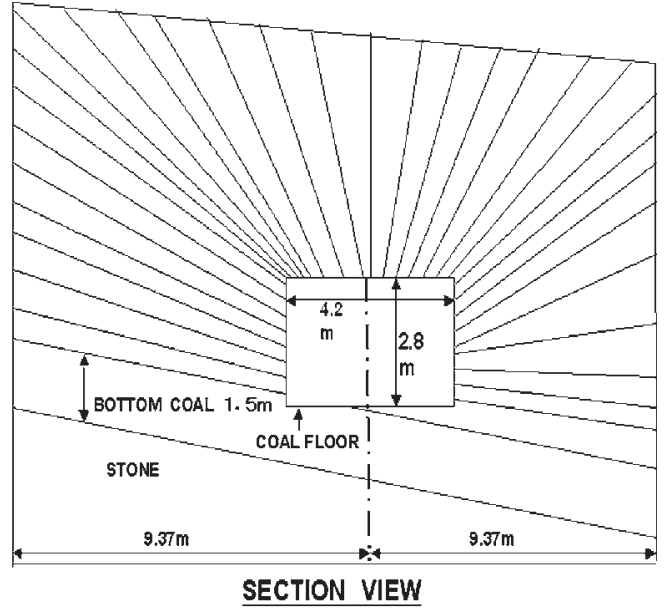

Fig.8 Ring blasting pattern.

要である。

\section{4. 新しい厚層採掘システム}

炭層が固く, 厚く, 自然発火しやすく, かつ難崩落性の上盤で ある場合には別の採掘法を適用する必要がある。長壁式法やルー ム\&ピラー法，あるいは両者を併用して採掘跡を充填しながらス ライシングで採掘する方法について可能性をさらに追求する必要 がある。

これまで採掘跡の充填は, 充填に伴うコスト増や低い生産性の
ために本格的に導入されることはほとんどなかった。しかしなが ら, 充填システムの改善や石炭の採掘, 利用に伴う種々の環境問 題はこれまでの考え方を一新する機会となってきている。

インドにおいては, 露天掘りに伴う大量のボタの発生と石炭火 力発電所からの年間 1 億トンを超える石炭燃焼灰の処理が大きな 環境問題となってきている。これらを用いた払跡への効率のよい 充填システムを構築することにより，これまで採掘ができなかっ た石炭までも採掘することができるようになり，持続可能な石炭 の生産と環境負荷低減型の採掘が可能となる。なお, 前述したよ うに石炭灰スラリーを払跡に散布し, 残炭の表面を被覆すること で自然発火を防止することができる。このスラリー散布システム は, これまで我が国の坑内掘り炭鉱での袖巻き充填や坑道密閉, 漏風防止対策, 自然発火防止対策等で用いられてきたフライアッ シュの流送システムを活用することが出来ると考えられる。この ようなシステムは現在インドで用いられている採掘システムに直 ぐにも活用することができる。

\section{5. 結言}

今後の我が国のエネルギー事情や世界に対する貢献を考える と，アジアにおいて中国に次いで 10 億以上の国民を抱えるイン ドの存在は無視することができない。これまでに我が国の石炭鉱 業界が長年にわたって培って発展させてきた高度な坑内採掘や保 安技術をインドの鉱山, 特に坑内掘り石炭鉱山に積極的に移転す ることにより，生産性を上げ，インドが必要とする石炭を自らが 安定して国内で確保することは, 我が国のエネルギーの安定供給 上きわめて重要である。

技術協力で考慮すべきは，生産性を向上させ，保安を確保する 


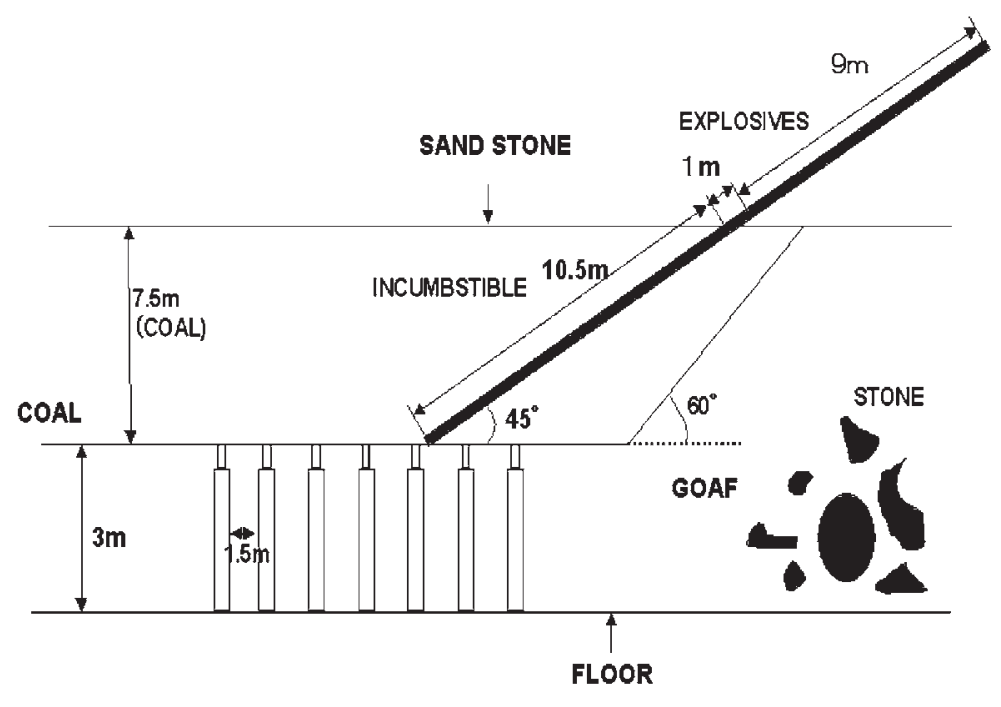

SIDE VIEW

Fig.9 Induced blasting for hard roof rock.

のみならず，地域雇用を促進するものである必要がある。新しい 技術やシステムの導入に伴う生産性の増大が地域住民の雇用の機 会を奪うような状況となることは是非とも避けなければならな い。

炭鉱を現地調查したインドの炭鉱坑内は昭和初期と昭和 50 〜 60 年代が混在した印象である。基本通りに坑内採掘設計がなさ れている一方で, 生産計画に対して過剩能力と思われる設備が導 入されているなど技術選択基準がアンバランスな印象を受けた。 インド側から要望された生産性向上や保安確保のための課題をま とめると以下の通りである。

1) 坑内通信システム (モバイルタイプ)の早期導入

2）坑内各種モニタリングシステムの導入

3）自然発火の早期検知・消火システム及び制御技術の開発

4）厚層下での採掘システムの開発

5） LW システムの生産性増大

6）坑内水の影響下での LW 切羽の設計

7）天盤に軟弱層を含む場合の支保システムの確立

8）累層採掘下での LW パネルの設計と下層パネルの必要自走 枠能力の算定法
9） $47^{\circ} \mathrm{C}$ を超える夏期における通気改善

謝辞＼cjkstart本報告は, 石炭エネルギーセンタ (JCOAL) の平成 15 年度の調查事業及び日本学術振興会 (JSPS) の事業に基づいてお り, インド国立岩石力学研究所 (NIRM) 及び CIL, WCL, SCCL には鉱山の見学, 資料収集等にご理解とご協力を賜った。ここに 記して深く謝意を表する。

\section{References}

1) JCOAL: Coal Field in the World (1999), pp.369-409 (in Japanese)

2) S. Tadisetty, G.N. Gupta, K. Matsui \& H. Shimada: Coal Mining in India, Proc. MMIJ Fall Meeting (2003), Vol. AB, pp.205-208.

3) R.M. Bhattacharya, N.C. Karmakar \& P.K. Banik: Journal of Mines Metals \& Fuels (2002), January-February, pp.34-38

4) W.Jian: Proc. of Asia-Pacific Workshop on Coal Mining Technology in Tokyo '97(1997), pp.141-150

5) P.K. Mandal, A.K. Singh, O.P. Singh, J. Buragohain \& R. Singh: Journal of Mines Metals \& Fuels (2002), January-February, pp.25-33

6) K. Matsui, H. Shimada \& S. Tadisetty: Proc. MMIJ Annual Meeting (2003), Vol. I, pp.158-159. 